University of Massachusetts Amherst

ScholarWorks@UMass Amherst

Masters Theses 1911 - February 2014

1987

\title{
The effect of background information on object identification.
}

Susan J. Boyce

University of Massachusetts Amherst

Follow this and additional works at: https://scholarworks.umass.edu/theses

Boyce, Susan J., "The effect of background information on object identification." (1987). Masters Theses 1911 - February 2014. 2123.

Retrieved from https://scholarworks.umass.edu/theses/2123

This thesis is brought to you for free and open access by ScholarWorks@UMass Amherst. It has been accepted for inclusion in Masters Theses 1911 - February 2014 by an authorized administrator of ScholarWorks@UMass Amherst. For more information, please contact scholarworks@library.umass.edu. 
UMASS/AMHERST

.

31,2066007625251 


\section{THE EFFECT OF BACKGROUND INFORMATION ON OBJECT IDENTIFICATION}

\section{A Master's Thes Is Presented}

By

SUSAN J. BOYCE

Submitted to the Graduate School of the University of Massachusetts in partiai fulfiliment of the requirement for the degree of MASTER OF SCIENCE

SEPTEMBER, 1987

Psychology 
THE EFFECT OF BACKGROUND INFORMATION

ON OBJECT IDENTIFICATION

A Master's ThesIs Presented

By

SUSAN J. ROYCE

Approved as to style and content by:

Alexander Pollatah

Alexander Pollatsek, ChaIrperson of Comm lt tee
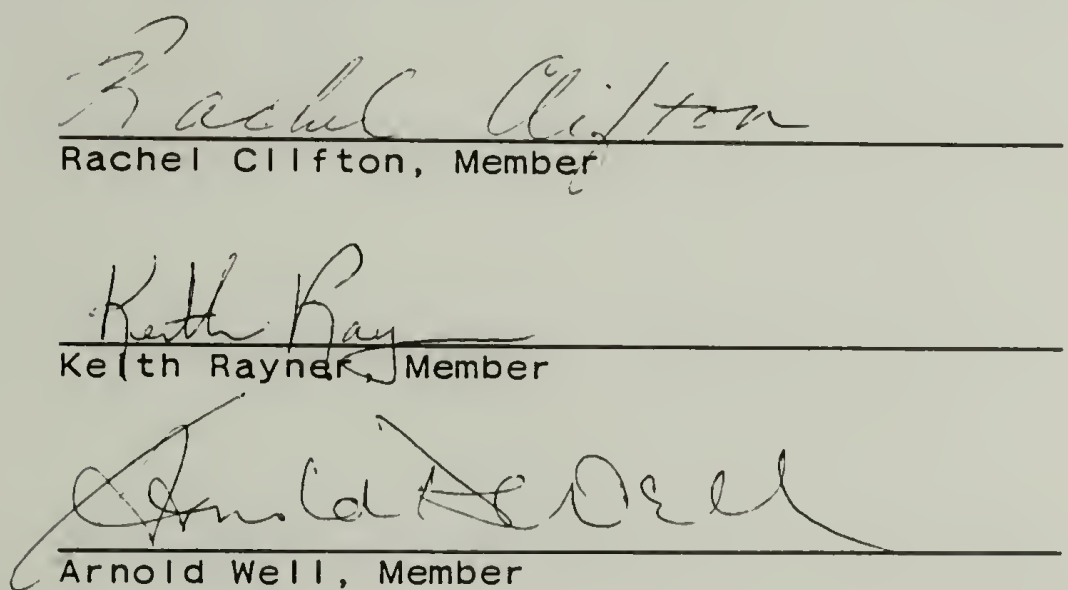

Arnold Well, Member

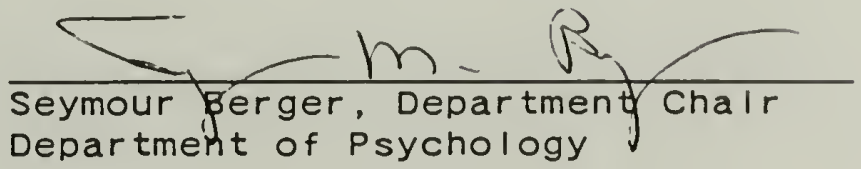




\section{AKNOWLEDGEMENTS}

1 would like to thank the members of my committee, Rachel Clifton, Kelth Rayner, and Arnie Well. I especlally want to thank the chair, Sandy Pollatsek, for his time and effort spent on this project.

In addition, I would like to thank Harry Blanchard for his assistance. His support throughout all aspects of this project was Invaiuable to me. Also, I would I Ike to thank the artist, Earle Smith, for drawing the scenes. 


\title{
ABSTRACT
}

The Role of Background on Object Identiflcation

\author{
(September 1987) \\ Susan J. Boyce B.S., Ursinus College \\ M.S., Unlversity of Massachusetts \\ DIrected by: Professor Alexander Pollatsek
}

This thesls examines the role that scene backgrounds play in object ldentiflcation. Prevlous research has Indicated that objects located in a coherent scene are easler to Identify. Thls research employed the brlef presentation method used in prevlous research on scene perception. Experlment 1 Indlcates that objects are more difflcult to ldentify when they are located in an "eplsodically" Inconslstent background. Experlment 2 demonstrates that the degree to whlch non-cued (cohort) objects are conslstent w/th the target object has no effect on this object ldentiflcation task. Experiment 3 shows that consistent eplsodic background Information facllitates object Identiflcation and Inconsistent eplsodlc background Information does not Interfere. The results of these studles Indlcate that models of scene perception wIII have to be modifled. 
ACKNOWLEDGEMENTS

ABSTRACT

LIST OF TABLES

CHAP TER

1. INTRODUCTION

Overview

Object Identification and

Scene Coherence . . . . . . . . . . . . . . . 3

Object Recognition and scene

Coherence

Eye Movement Research and

Scene Perception . . . . . . . . . . . . . 15

A Definition of "Coherent Scene"

Inferred from StImulI and

Manlpulations in Previous Research . . . . . 19

The Role of Backgrounds in Coherent

Scenes.

Potent|al Roles of Background

on Object IdentIfIcatIon......... . . . 21

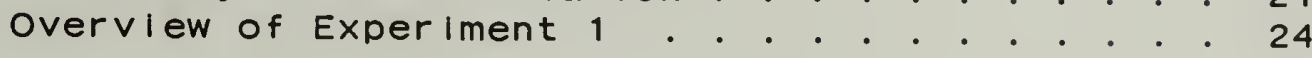

2. EXPERIMENT 1 1 . . . . . . . . . . . . . . . . . . . . . 27

Introduction . . . . . . . . . . . . . . . 27

Method . . . . . . . . . . . . . . . . . 27

Subjects . . . . . . . . . . . . . . . . . . 27

Scenes . . . . . . . . . . . . . . . . 27

DesIgn . . . . . . . . . . . . . . . . 28

Apparatus . . . . . . . . . . . . . 30

Procedure . . . . . . . . . . . . . . 30

Results... . . . . . . . . . . . . . . . 31

Dependent Measures . . . . . . . . . . 31

Accuracy . . . . . . . . . . . . . . . 33

Error Data - Mlsses and
False Alarms . . . . . . . . . . . . . . . 35

DIscussion . . . . . . . . . . . . . . 36

3. EXPERIMENT 2 2 . . . . . . . . . . . . . . . . . . . . . . 41

Introduction . . . . . . . . . . . . . . . . 41

Method . . . . . . . . . . . . . . . . . 42

Sub Jects . . . . . . . . . . . . . . . 42

Scenes................ . . . . . 42

DesIgn... . . . . . . . . . . . . . . . . 44

Apparatus and Procedure . . . . . . . . 44 
Results . . . . . . . . . . . . . . . . . . . . . . . . 45

Error Data - Misses and . . . . . . . . . 45

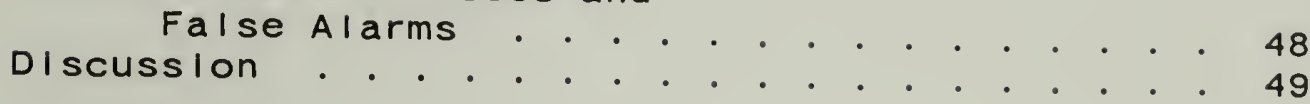

4. EXPERIMENT 3 . . . . . . . . . . . . . . . . . . . . . . 54

Introduction . . . . . . . . . . . . . . . 54

Method . . . . . . . . . . . . . . . . . . . . 55

Subjects . . . . . . . . . .

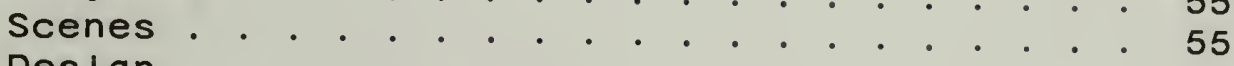

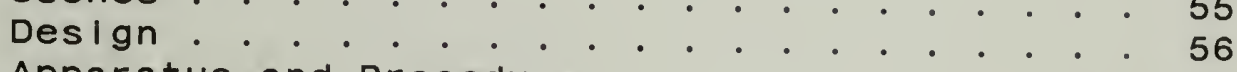

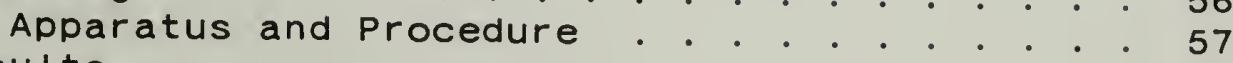

Results... . . . . . . . . . . . . . . . . . . . . 57

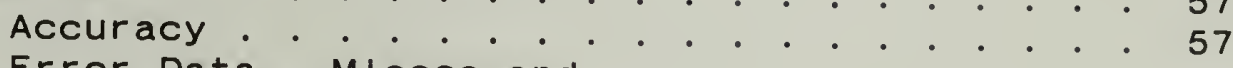

Error Data - MIsses and

False Alarms . . . . . . . . . . . . 59

Discussion . . . . . . . . . . . . . . . . . 61

5. GENERAL DISCUSSION . . . . . . . . . . . . . . 64

APPENDIX • . • . . . . . . . . . . . . . . . . . . . . . . . 74

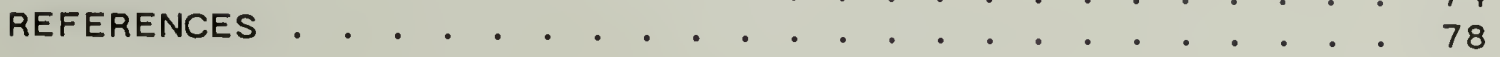




\section{LIST OF TABLES}

1. Mean Percent Correct and Mean d' on object

Identiflcation Task In Experiment 1

2. Mean Percent MIsses and False Alarms for Exper Iment

3. Example of Scene as it Appears In the Conditions of ExperIment 2

4. Mean Percent Correct in Experiment 2 . . . . . . . . 46

5. Mean $A^{\prime}$ for Experlment 2 . . . . . . . . . . . . 47

6. Mean Percent Misses and False Alarms for

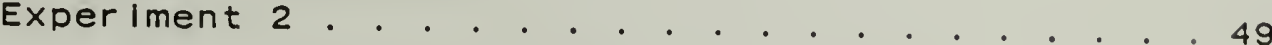

7. Mean Percent Correct and Mean $A^{\prime}$ on Object Identiflcation Task for ExperIment 3 . . . . . . 58

8. Mean Percent Misses and False Alarms for Exper Iment 


\section{INTRODUCTION}

Experiments on the perception of plctures have suggested that the ldentiflcation of an object is alded If the object Is located In a "coherent scene". ThIs work has generally focussed on degrading a coherent scene in some way In order to observe the decrement in performance. This has been done by alterlng the contents of the scene and by presenting the scene for brlef durations to degrade the amount of Information obtalnable from the visual display. However, a question that has not been entIrely answered is whlch aspects of scene coherence affect object Ident I f Ication.

A coherent scene conslsts of objects that can co-occur In the real world (objects meeting this crlterlon wIII be referred to as "eplsodlcally related"). Further, these objects must be Interacting with one another in a manner that Is conslstent with what we know about the objects: most objects must obey physlcal laws and constralnts due to the function of the object (e.g. a chalr must obey the law of gravity and be orlented In such a way that it can be sat upon). However, even If a group of objects meets these requirements they do not necessarliy constitute a scene. Well formed scenes also have backgrounds whlch provlde Information about depth and the spatial relations of the 
objects. Further, the background could convey global semantic Information that helps to determine the setting of the scene.

\section{Overvlew}

In the first section of this revlew I wIII focus on the role of scene coherence on object Identiflcation. Most of the work In this area has employed the brlef display paradigm In order to degrade the quallty of the scene Information. Generally, the results from these studles are Interpreted as evidence for rapid access of "scene schemas" that facliltate object Identiflcation.

The second section summarlzes some of the literature on recognition memory for objects in coherent scenes. The theory of scene perception that emerges from this I Iterature Is rather vague, but it resembles the schema activation argument outlined by Blederman and hIs colleagues in the object Identiflcation section.

A brlef summary of some of the research employing eye movement monltoring technlques wll! be revlewed in the third section. Some of the results from these studies are conflicting, but Interestingly enough, the results are al I Interpreted as evidence for rapld schema activation facll Itating object IdentIflcation.

The final section of the introduction is an attempt to define the role of backgrounds In scene coherence. Scene 
backgrounds have been employed in almost all research on plcture processing, but little attention has been pald to the role these backgrounds may be playing. In this section I wIII outline some posslble roles of background Information.

\section{Ob Ject Identiflcation and Scene Coherence}

Early work on object Identification In coherent scenes was conducted by Blederman and $h I s$ colleagues. Blederman's early work in scene perception employed photographs of scenes that were cut into sections. The sections were Jumbled (resulting in incoherent scenes) or left in their approprlate positions. These coherent and jumbled scenes were presented to subjects for brlef exposure durations (100-150 ms). In two such studles (Blederman, Rablnowitz, Glass and Stacey 1974; Blederman 1972) subjects were asked to Identify objects in jumbled and non-jumbled scenes that were presented brlefly. They found that jumbling reduced the accuracy of identlfylng objects, even though the objects remalned Intact and in thelr approprlate positions. However, Blederman found that the effect of jumbling was reduced If subjects were pre-cued for location of the target object and were shown the plctures of the objects before st Imulus onset. Blederman et al. concluded from thls I Ine of research that when a scene was brlefly presented, 
getting an "overall characterlzation" of the scene helped to Identify an object if 1) you did not know what you were looking for and 2) you did not know where to look.

Biederman's Jumbled picture studies were designed to determine the degree to whlch destruction of the semantic coherence of the scene Interfered with object Identification. However, the Jumbiling technique disturbs more than just the overall coherence of the scene. Intact scenes were photographs of objects in their backgrounds: therefore much of the depth information was conveyed in the gradual shading differences within a background. When the picture was divided Into six equal sections and put together in the Jumbied configuration, non-target objects were sometimes divided between two sectlons. Further, Jumbilng Introduced sharp contours that replaced gradual shading differences in background Information in the non-Jumbled scenes. Consequently, Jumbiling scenes in the manner of Blederman's early experiments does more than simply disturb the semantic coherence of the scene. The procedure results In the addition of fragments of objects and uninterpretable contours, thus not just destroying information but adding new information that was possibly disruptive.

In order to rule out the posslblilty that his effects in the jumbling studies were due to uninterpretabie background Information Blederman (1981) conducted a study almed at determining how background Information interacts 
WIth object IdentIflcation. He prepared stimull consisting of semanticaliy unrelated objects positioned In a depth background, a grid background, and a blank background. Subjects were presented wlth the sequence of events: 1) the target name, 2) the plcture slide for $200 \mathrm{~ms}$, and 3) a location cue. Thelr task was to Indlcate whether or not there was agreement between the target name and object at the cued location. Surprisingly, error rates were highest In the depth background condition and about the same in the no background and grld background condltions.

Blederman concluded from this result that depth Information has an effect on object Identiflcation only if It alds in forming a coherent semantic representation (whatever that means). He argued that with these stimull, no such representation could be formed because the objects were semanticaliy unrelated, and thus that capacity used trying to construct this coherent representation took away from one's ablilty to Identify the objects.

Another experiment (Blederman, Glass \& Stacey, 1973) conducted with jumbled vs. non-jumbled plctures employed a visual search task Instead of the prevlously mentloned rapld presentation method. The manipulations of Interest were whether the object sought was or was not present in the scene and whether the object was I Ikely or unlikely to occur In that scene. Subjects were Instructed to view the plcture until they found the target object or determined that the 
target object was not present. HIgh error rates were obtalned In the conditlons where the object was present and unlikely and where the object was likely but not present. very low error rates were obtalned in the condition where the object was unllkely to occur and was not present. Reaction times were faster overall for coherent scenes. Subjects were fastest at respondlng "no" when the target was unlikely to occur, next fastest for "yes" responses, and slowest for "no" when the target was IIkely to occur in the scene but was not present.

Blederman clalmed that subjects very quickly accessed a global meanlng of the scene slnce they made more errors when the object was present and not IIkely, and when the object was I Ikely but not present. ThIs global scene meanlng, or schema, alded object Identiflcation for consistent Items. Since subjects were faster at finding and Identifying objects In the coherent scenes Blederman clalmed that Jumbling was responsible for delaying this schema act Ivation.

Other explanations of these data exist that do not require positing schemas to ald in object Identiflcation. There is no doubt that as we move our eyes around a scene we are bullding a coherent representation of that scene. However, the relationship of this schema activation process to that of actlvating Individual objects is not clear. First, it is not clear whether schema activation can occur 
rapldiy enough to ald the Identiflcation of Individual objects. Second, even if schema activation preceeds Identiflcation of objects, it is an open question whether it Influences the process of object Identiflcation. Blederman et al. data does not directly answer these questions. Subjects could have ldentifled one or two objects in the scene and declded "no" If the target object was unl ikely to be plctured with the Identlfied objects. If it was plauslble that the target object could coexist in a scene with the ldentifled objects then the subjects kept searching. If the target object is present, they wIII fInd It before they have examlned all objects in the scene (on average) and $\mathrm{WIII}$ be able to respond "yes". If the target Is not present, the subjects must do an exhaustive search of all objects in order to respond "no". Thls strategy would account for Blederman's findings and does not require schema activation. Subjects could have just adopted a consclous strategy of declding the l Ikel Inood of the target object appear Ing in the same scene as the one or two objects they InItIaliy Identified.

Thls early research led to a flurry of experiments conducted by Blederman and $h$ ls colleagues to determ lne more speciflcally when schema activation might occur and the mechanisms of this activation. Blederman. Mezzanotte, and RabInow Itz (1982) attempted to determIne whether coherence and thus schema activation was due to the relationships 
between the objects in a scene. They Identifled flve "scene relations" that make up a coherent scene.

1. Support - Most objects rest on surfaces.

2. Interposition - Opaque objects occlude thelr background.

3. Probabllity - Degree to whlch an object is I Ikely to occur in a given scene.

4. Position - Degree to which an object is IIkely to occur In a given scene at a partlcular spatial location.

5. Size - Degree to whlch an object is of an approprlate size given the slze of the objects surrounding It.

Furthermore, Blederman et al. make a distinction between syntactic relations ( 1 and 2 above) and semantlc relations $(3,4$, and 5 above). Thls distinction is based upon the clalm that detection of a syntactlc violation does not require Identiflcation of the object in question, and that detection of a semantic violation requires accessing object Identiflcation Information. Blederman argues that a bottom up model of scene recognition (e.g. Marr, 1982) predicts that syntactlc violations would be accessed by the perceptual system sooner than semantlc vlolations, because aspects of the object (I.e spatial location) would be accessed before object Identlfication. Thus, If lack of support was detected thls would interfere at an earller 
processing stage than if a semantic relation was violated. The earlier the interference occurs in processing, the more disrupted performance should be on an object identification task.

Blederman et al. (1982) presented subjects with brief dIsplays ( $150 \mathrm{~ms}$ ) of scenes with objects undergolng varlous relation violations. Subjects were given the name of the target object prlor to each trial and then were given a location cue and mask after the presentation of the scene. The subjects task was to Indlcate if there was agreement between the object in the cued location and the name presented before the display.

Objects undergolng violations Incurred a higher miss rate and a silghtly higher false alarm rate than objects that were presented in their base positions. Thus, Blederman argued that objects undergolng violation are harder to percelve. However, this effect was no less for objects undergoing semantic violations than for objects undergolng violations of elther support or interposition Indicating that semantic violations are at least as disruptive as syntactic violations. Objects undergoing multiple violations were ldentifled less accurately than objects that were vlolating only one relation.

A second experiment was conducted that involved the detection of the violations themselves. Subjects were precued for the location of the potentlal violations and after 
a brlef presentation of the scene were to respond "yes" or "no" as to whether a violation was present at that location. The results were congruent wIth those from Experlment 1 : the semantic violations were detected at least as accurately as the syntactlc violations. Furthermore, multiple violations were easler to detect than single vlolations.

From these results Blederman concludes that objects undergolng violation are harder to see than objects not undergolng violation. Further, he clalms that, slnce violation of a non-cued object did not Interfere with object recognition for a cued non-violated object, that the elicltation of schemas for these scenes was not disrupted by the presence of a violation somewhere in the scene. In fact, he states that violation costs were the result of schema Interference on object Identiflcation. As a result of thls research Blederman and colleagues reject a purely bottom-up model of scene processing.

The argument agalnst the bottom-up model relles heavily on the syntactic-semantic distinction. The result that semantlc violations were as disruptive as syntactlc violations seems to Indlcate that the bottom-up model is Incorrect. However, the syntactic-semantlc distinction may not be valld. In order to reallze that an object is undergolng a violation of support, one has to obtain enough Information about that object to determine whether It requlres support. Blederman (1982) has since conceded that 
object Identification would be necessary to determine whether an object was undergolng the support violation. However, he counters by saylng that the detection of the lack of support for an object does not require that we know what that object is. He argues that lower level assignment of surfaces durling an object parsing stage would provide this kind of information. This may be true, but it does little to further the case of the syntactic-semantic distinction he is trying to defend. Identifying that an object is not supported is not the same as identifying that an object is violating the relation of support. in order to determlne whether the lack of support is a violation or not still requires object Identification. ThIs same argument holds true for Interposition relation as well.

The work summarlzed here along with other research led Blederman. to belleve that schema actlvation occurs very early In the course of plcture vlewlng. Further, Blederman clalmed that the route to schema activation is not objectsthen-schema as has been proposed by Frledman (1979) and others. The route that he advocated requires the use of the relations or Interactlons between the objects of the scene and he asserts that thls Information is avaliable before the objects are fully ldentifled.

The research conducted by Blederman and his colleagues does Indicate that subjects are abie to gain some Information from very brlef exposures to plctures. His 
evidence for accessing relations between objects before the objects themselves have been Identifled seems weak. However, these experlments all clearly Indlcate that when scene coherence is destroyed subjects are less IIkely to recognize a target object in a scene. Experiment 2 in the present set of experiments wll I test Blederman's route to schema activation.

\section{Object Recognition and Scene Coherence}

Antes and varlous colleagues have also attempted trying to sort out the kinds of information a viewer can get from brlef displays of plctures. Antes (1977) presented subjects with $100 \mathrm{~ms}$ displays of scenes then tested subjects for recognition of sections of the scene. The sections were created by dividing the plcture into equal parts (much as Blederman had done) and the sectlons were rated as belng of high, medium, or low "Informativeness". He found that accuracy on the section recognition task depended on the rated Informativeness of the section (subjects were more accurate for highly informative sections) and on the eccentriclty of the section (subjects were more accurate if the test section had been located near the center of the plcture). A second experiment employing the same methodology tested subjects' ablilty to recognize the location of a target section. Subjects were presented with 
the scene and then a target section of that scene. Their task was to Indlcate where In the scene that section had appeared. Accuracy on thls task was lower overall than on the section recognition task but performance was still affected by the Informativeness of the section and by the eccentricity of the target section. Since subjects were more accurate at recognizing the section than locallzing the section Antes proposed that object IdentIflcation and object localization are mediated by two different processes and that the process responsible for locallzation is slower. The evldence for thls model seems pretty weak.

In an experiment geared toward Identifylng global versus local processing of scenes, Antes, Penland, and Metzger (1981) presented subjects with brlef displays of scenes followed by an object recognition task. The manlpulations of Interest were scene context (hlgh or low). usualness of target object (usual or unusual with respect to context of scene), and consistency of distractor Information (consistent or Inconsistent with respect to context of scene). "HIgh context" scenes were well formed scenes WIth coherent backgrounds and many objects, whlle "low context" scenes were created by deleting the background and some of the objects from the hlgh context scenes. Subjects saw a $100 \mathrm{~ms}$ exposure of the scene followed by an array of four objects (three distractor objects and one that had appeared In the scene). Subjects were Instructed to choose the 
ob Ject that they had seen in the display.

For $\mathrm{hlgh}$ context scenes subjects were most accurate if the target object was conslstent with the context and the distractor objects were Inconsistent with the context. Subjects were less accurate If the distractor objects were also conslstent wIth scene context and performance was poor when the target object was unusual with respect to the context of the scene. Thus, probablilty of correct recognition of an object was Influenced by both usualness of the target and usualness of the distractors. In contrast, performance of subjects presented with low context "scenes" were not affected by the usualness of the target object or consistency of distractor objects. Antes et al. ran a third group of subjects that were not presented $w /$ th the scene at al I but Instead read a one sentence discrlptor of the theme of the scene. These subjects then chose an object from the array of four objects that was IIkely to occur in a scene with the partlcular label. The pattern of data obtalned from this "thematic Information group" Is very similar to the data collected from the high context group.

From this study Antes et al. conclude that global scene Information is avallable after $100 \mathrm{~ms}$ of viewing a scene. Because the results from the thematic Information group parallel those from the hlgh context group, Antes advocates a "scene emergent features" route to schema actlvation. According to this theory, the first fixation on the scene 
provides global information about the setting, thus al iowing the viewer to cali upon knowledge about which objects to expect in the scene. HIs evidence against the objects-thenschema route is the similarity between the thematic information group and the high context group. If schema activation occurs as the result of Identifying one or two objects in the scene, then the high context unusual target object group should have accessed the wrong schema on trials where the unusual object was identlfied first. This shouid create a discrepancy between the high context group and the thematic information group and this descrepancy was not evident in the data.

Unfortunately, Antes is not able to define what these "scene emergent features" might be. Blederman defines them In terms of relations between objects. But if one is to belleve the results of Antes (1977), Information about an object's location is accessed only after object Identiflcation has occurred. This leaves a somewhat muddled plcture about how context heips in plcture viewing.

\section{Eye Movement Research and Scene Perception}

Research on the role of context on object Identification has not been I Imited to paradigms that employ brief presentation of scenes. Many researchers have recorded eye movements during scene viewing to determine the 
role of scene context on a subject's fixation duration and pattern of flxations. Loftus and Mackworth (1978) were Interested In determInIng where people wIII look In a scene given the opportunity to vlew the display for 4 seconds. Some of the scenes they presented contalned objects that were very unlikely to occur glven the scene context (I.e. octopus In a farm background, tractor in an underwater background). They found that low probabllity objects were flxated earller, were flxated more often, and were flxated for longer durations. From these data Loftus and Mackworth clalm that subjects readily obtaln the "glst" of the scene (wIthin the first fixation) and partially Identlfy objects In the perlphery. ThIs partial object Identiflcation then leads subjects to compute conditional probabllitles that these objects are likely to occur glven the gist. Subsequent fixations are then presumably gulded to those objects whose conditional probabllitles are lowest.

The examples of the stimuli used in this experiment, If representative of the stimull set as a whole, provide an alternative explanation of these data. The octopus in the farm background is not only semantically or eplsodically different from the rest of the scene but is also different in terms of low level perceptual features. The farm background consists predominantly of stralght I Ines and right angles, whereas the octopus is deflned by Irregular contours and wavy IInes. Subjects could have flxated the 
octopus earller and for longer durations because of this contour difference and not because they were belng Influenced by the semantics of the object.

If the stimull presented in the article were not representative of their stimuli in general, and thelr results really do Indlcate that subjects will look to objects that are not probable, then the route to obtalning the glst of the scene must be rapld processing of the background information. ThIs would argue that a scene that elther had no background, or a noninformative background would be processed in a different manner than that out IIned by Loftus and Mackworth.

Antes and Penland (1981) conducted a sImllar study: they recorded eye movements during $v$ lewing of scenes that contalned high probabllity and low probabllity objects. An additional manipulation was included in this study: the degree of background context. HIgh context and low context scenes were defined as In the Antes, Penland and Metzger (1981) study described above. They found that first flxations on expected objects were shorter when they occurred in hlgh context than when they occurred in low context. First flxation durations on unexpected objects were the same In both the hlgh context scenes and the low context scenes. Data collected on the average saccade length Indlcated superlor per Ipheral IdentIflcation of objects that were consistent with the context than of objects that were 
inconsistent with the context. Concerning the probability of fixating a I Ikely object versus an unilkeiy object. Ilttle can be sald from thls study, because probability of an object occurring in the scene was confounded with location in the scene so that more unexpected objects occurred In the center of the scene where subjects began vlewling. An attempt was made to sort out this confounding and Antes and Penland concluded that objects consistent $w /$ th the context were more I Ikely to be fixated early In view Ing whlle durlng later viewling the pattern switches so that unexpected objects are more IIkely to be fixated.

Both Loftus and Mackworth (1978) and Antes and Peniand (1981) argue that the theme or glst of the scene can be obtalned very rapldiy which results in actlvating schemas for these scenes. It is Interesting to polnt out that this concept of schema activation does not constraln the predictlons that can be made concerning the likel lhood of a glven object belng $f$ Ixated. Loftus and Mackworth claim that this schema activation results in fewer flxations on likeiy objects while Antes and Penland argue that schema activation results in more flxatlons on expected objects. Perhaps a better understanding of how schemas are activated may make clearer what schemas are and may help constrain the theory. Varlous other studies have been conducted using eye movements to Investigate scene perception (Mackworth and MIrandI, 1967; Nelson and Loftus, 1980; and Salda and Ikeda, 
1979). Results of these studies are in many ways conflicting in that the schema argument can be used to predict many outcomes. Varlous other people have studled memory for plctures (Frledman, 1979; Parker, 1978). Thls I Iterature wIII not be revlewed at this time since the Issues that are dealt with in recognition memory for plctures may be quite different than those concerning Identiflcation of scenes.

\section{A DefInItIon of "Coherent Scene" Inferred from StImulI and Manlpulations In Prevlous Research}

The research revlewed above, when taken together as a whole, appears to share a common definItion of "coherent scene". The coherent scenes that have been used in these experlments have common elements. Flrst, coherent scenes always conslst of objects that are eplsodically related; meaning that the objects could co-occur in a real world scene. Second, these objects must malntaln certaln physlcal relationships with one another as Blederman et al. have Indlcated. Objects must obey physlcal laws (I.e. gravity, opaque objects occlude thelr backgrounds, etc.). Furthermore, objects must be placed in the scene in such a way as to establish a conslstent viewpolnt (1.e. objects further away look smaller). ThIrd, well formed scenes have a "background". This third crlterion for well formed scenes 
WII be the focus for the rest of the paper.

\section{The Role of Backgrounds In coherent Scenes}

The well formed scenes employed in the experiments reviewed above have all included some type of background Information, yet surprisingly little has been sald about the role this information plays in achleving the meaning of a scene.

Blederman (1981) touched on the role of backgrounds in his investigation of depth gradients and object Identification. Depth gradients actually Interfered with one's ablilty to ldentify objects. However, the scenes that he used were not coherent. The objects violated eplsodic relatedness and the backgrounds were merely converglng I Ines constructed to establish a viewpolnt for the subjects. Blederman concluded that background Information (or more precisely, depth information) should help only if the objects are eplsodically related, but this fact has not been estabI Ished.

Antes, Penland, and Metzger (1981) also tangentlally dealt with the role of backgrounds by nature of the way they defined hlgh and low context plctures. The hlgh context scenes used in this study contalned many objects (some more definlng of the scene than others) as well as falrly complex 
backgrounds. The low context scenes were created by deleting the background and some of the objects from the hIgh context scenes. Antes et al. found object recognition performance was much better In the hlgh context scenes than In low context. Unfortunately, because some objects had been removed as well as the background to create low context scenes, no conclusion can be drawn concerning the role that the background Itself plays in providing context (this was also true of Antes and Penland, 1980, revlewed above). Furthermore, because Antes did not report how he chose the objects to be deleted, it is possible that some context definlng objects (objects that can only fit in that scene) were deleted, which would create a decrement in performance.

Potentlal Roles of Background Information on Object Identification

Background information may provide context by helping to estabilish a unique viewpolnt for the scene and by providing depth cues. By unlque viewpolnt 1 mean establishing whether it is a top vlew, or a vlew from the left corner of the room etc. ThIs is much the way Blederman expected hls depth gradients to function. It is possible that some of the relations between objects that Biederman has Identifled are dependent upon background function Ing in this manner. For example, violations of relations of size 
and support should be very difflcult (maybe Impossible) to detect if background depth information is missing. it is not clear how one can, without depth information, determine If an object is in an approprlate place and if it is the correct size. It may be possible to construct depth information from the objects if none is given by the background, but this process would take much more time.

Another way in which backgrounds may function is by provlding "eplsodic cues": the background provides some Information as to the theme or meaning of the scene. For example, a Farm Background may contain a barn in the distance, fences around flelds, and perhaps rolling hills in the distance. In this regard, backgrounds may function as large objects with recognizable features. Perhaps what subjects obtain from brlef presentations of scenes is background information that then allows them to infer the objects that are likely to occur in that background.

The experiments reviewed above indicate that scene context does alter our ablilty to correctly ldentlfy and accurately remember objects. When scenes are coherent Identification of objects appears to be facliltated and we are more likely to remember objects that were consistent with the context. However, it is not clear from the above studles the degree to which this apparent facllitation from scene context is due to critlcal objects in fovea, or critical aspects of the background. The question left 
unanswered is the degree to whlch benefits from scene context are due to the eplsodic consistency of the backgrounds.

The experlments reported here are deslgned to examine the role of background Information on the Identiflcation of obJects. ExperIment 1 establishes whether depth gradient Information alone is sufflclent to facliltate object Identiflcation or whether eplsodic, setting Information is obtalned from brlef displays of scenes.

All three experlments employed the brlef presentation method used by Blederman and others. Conceptually, this task is trylng to mimlc what might occur during the first $150 \mathrm{~ms}$ of scene processing, or roughly the fIrst fIxation on a scene. There are a number of reasons why brlef exposures may not mImIc first fIxations. FIrst, when subjects know they are only golng to have $150 \mathrm{~ms}$ of vlew Ing time they may allocate spatlal attention differently. Perhaps an attempt Is made to "wIden" thelr spotilght of attention to take In as much of the display as possible and, to the extent that they are successful in this, there may be a decrement in processing the foveal Information. Another posslble problem with this task is that concluslons about the time course of processing are not stralghtforward. The visual display is terminated $150 \mathrm{~ms}$ Into a trlal and subjects' responses (yes or no in the object Identiflcation task) generally are produced about 1000 ms after the display is termInated. 
ThIs $1000 \mathrm{~ms}$ response $t$ Ime is not only reflecting the time to engage in a motor movement (for a button press or vocal response) but also reflects decision time, or "postperceptual" processing.

The decision to use the brlef presentation method was made know Ing that the procedure was flawed in some respects. This method has been commonly used in plcture perception research so that It makes comparisons between the current studies and previous research relatively easy. Also, to some extent, all methodologles have flaws. Even eye movement research (whlch is by far the most on-I Ine measure aval $\mid a b l e)$ is not without assoclated problems. It could be debated that no measure from the eye movement record. such as first fixation duration or gaze duration is an uncontam Inated measure of the time to Identlfy an object. A f Inal reason for choosing the rapld presentation method was one based on pragmatlcs. Thls method was relatively easy to Implement and the equlpment was avallable.

\section{Overvlew of ExperIment 1}

The manipulation of Interest in Experiment 1 was whether the object to be Identifled was presented in an eplsodically consistent background, an eplsodically Inconsistent background or with no background at all.

Background conslstent scenes were coherent scenes with the background conveying Information about the setting of 
the scene. The objects located in the foreground were objects that are likely to occur in that setting. The objects were positloned in the background In such a way that does not vlolate any of Blederman's relations.

Background Inconsistent scenes consisted of well defined backgrounds that convey information about the setting of the scene. The objects located In the foreground were objects that are eplsodically related to one another, but could not occur in the background. The objects were positioned within the background so as not to violate relations of size or support.

Two no background control conditions were included in order to establish a baseline for the object identiflcation task. These no background condition "scenes" were created by deleting the background from the scenes in each of the two above conditions.

Blederman's model predicts that objects in the conslstent background scenes would be percelved more readlly than objects in the Inconsistent background scenes. Further, Blederman's model states that the route to schema activation (and therefore facliltation in object Identification) is through accessing relations between objects. Thus performance should be worse in the no background conditions than in the background consistent conditions, as no background scenes make lt very difflcult (maybe Imposslble) to ldentlfy the relations between the objects. 
The bottom-up model of object Identiflcation, proposed by Henderson. Pollatsek and Rayner (1987) poslts that scene context effects may be due to passive spreading of act Ivation between "obJect" nodes in a network. Tak Ing this position to the extreme, one would predlct no difference between any of the conditions In experiment 1 since the target object is always presented with related objects. However, If backgrounds function as "large objects" and are represented in the network as nodes the same as other objects in the scene, then one would predlct that performance on background consistent scenes would be better than performance on background Inconslstent scenes. 


\section{EXPER IMENT 1}

\section{Introduction}

Experiment 1 was designed to investigate the role backgrounds play in object ldentiflcation. Scenes were constructed so that objects appeared elther In eplsodicaliy consistent backgrounds, Inconsistent backgrounds or no backgrounds at all. The first purpose of this experiment was to determine if the degree of episodlc relatedness had an effect on object Identlfication, and second, whether conslstent backgrounds facllitated object Identification or inconsistent backgrounds Interfered with object IdentIflcation, or both.

\section{Method}

\section{Subjects}

Sixteen University of Massachusetts undergraduates participated in this experiment for extra credit in psychology courses. An experlmental session lasted approximately 55 minutes.

\section{Scenes}

The 64 scenes were constructed from an or IgInal set of 
16 coherent scenes. These 16 scenes were I ine drawings of common rooms of a house (e.g. Bedroom scene), common public places (e.g. Diner/iunch counter), and common outdoor scenes (e.g. Street scene) (see Appendix for a list and description of scenes). Each of the or IgInal 16 scenes consisted of a background and five objects and they were organized in 8 scene pairs with the constralnt that objects in both scenes In the palr be roughly equivalent in real-world size. The 16 Background Inconsistent scenes were created in the followlng manner: The objects in one scene were swltched for the objects in the paired scene. The placement of objects in the inconsistent background required that the objects be rearranged In the two dimenslonal frame in order not to violate support, and in no case was the object's retinal size altered. The two no background control scenes were created by eilminating the background from the 16 or Iglnal scenes and the 16 background Inconsistent scenes. The scenes subtended 16 degrees $\ln$ wIdth and 14 degrees in helght and the objects averaged approximately 2 degrees in width and 2 degrees in helght and were located 5 degrees on average from the fixation polnt.

\section{DesIgn}

The 64 scenes were created from 16 backgrounds and 16 object sets. Each subject saw each object set four times (one time for each background condition). However, a 
different object in the set was cued each time. For example, the kltchen slnk object set conslsted of a coffee maker, wine glass, toaster, eggbeater, and a bottle of dish washing I lquld. One of the five objects, the dish washing liquid in this case, was never cued. Selection of the object not to be cued was based upon the difflculty of labeling it and the degree to whlch the object was distingulshable as belonglng in that scene. One subject was cued for the coffee maker in the background conslstent condition, the toaster in the background Inconsistent condition, etc. Thls was counterbalanced across subjects withIn a given scene and within a subject across the different scenes. The correct answer (yes or no) was also counterbalanced so that for every subject half the correct answers were yes and half were no. Therefore, across a set of 8 subjects, all four objects would be tested in each background condition, half of the time when the object name was presented and half the tIme when when the name of an object not in the scene was presented. Two names of objects not present were needed for each scene for the no trials. These object names were chosen so that they were IIkely to flt In with the background (I Ist of these names can be seen in the Appendlx, labeled "dlstractor Items"). Trlals were presented in a random order, with the constralnt that no two consecutive trlais contalned the same background or the same object set. 


\section{Apparatus}

The scenes were dISPlayed on a Megatek WhIzzard Vector plotting CRT scope wIth a P-31 phosphor Interfaced wIth a VAX 11-730 computer. The computer controlled the exper Iment and recorded the subjects' responses and response $t$ Imes. The scenes were entered Into the computer by a summagraphlcs BIt-Pad.

\section{Procedure}

Subjects first read the name of the target object that appeared In the center of the screen In front of them. The name remalned on the screen for 3 seconds and was Immediately followed by a flxation cross In the center of the screen. The flxation cross remalned on the screen unt II the subject inltiated the trlal by pressing a response key. The scene appeared on the screen for $150 \mathrm{~ms}$ and was followed Immedlately by a mask (consisting of random I Ine segments and angles) with a "cue" embedded In It. The cue was a flled clrcle approximately $1 / 2$ In diameter. The location of the cue varled wldely, but it was always where an object had been present in the scene. The subject was Instructed to respond yes If the name presented at the beginning of the trlal was the name of the object present at the cued location in the scene. Subjects were to respond no if target name was not the object at the given location in the 
scene. Subjects' yes and no responses were made by pressing a response key with elther the middle or index finger of their right hand, respectively. After the subject had responded, the mask was removed from the screen. The next trial began with the target name presentation 8 seconds after the prevlous response had been made. The 128 experlmental trlals were divided Into 4 sets and subjects were given a $3 \mathrm{~m}$ Inute break between each set. The first two sets composed the first time through the 64 scenes (and $w / 1$ I be referred as Block 1) and the second two sets were the 64 scenes shown for a second time (Block 2). 32 practlce trials (using different scenes than those in the exper Imental trlals) were glven to each subject to ensure that they understood the task.

\section{Results}

\section{Dependent Measures}

The goal of Experlment 1 was to determine what aspects of background Information Influence accuracy on the object Identiflcation task. However, there is no single best measure of accuracy. One method frequently used is to look at the probablilty of hits (yes when object was present) and the probabllity of false alarms (yes when object was not present). If the probabllity of a false alarm decreases whlle the probabllity of a hlt Increases then assessing 
accuracy is pretty stralghtfoward. However, If an Increase In the probablIIty of a hIt is assoclated wIth an Increase In the probabl। Ity of a false alarm, then assessing accuracy or "sensitivity" is more of a problem. In all the experlments reported here false alarm rate Increased wIth the hlt rate. In some sense, "percent correct", averaging over yes and notrlals, corrects for the response blas problem. Other more theoretically based measures of

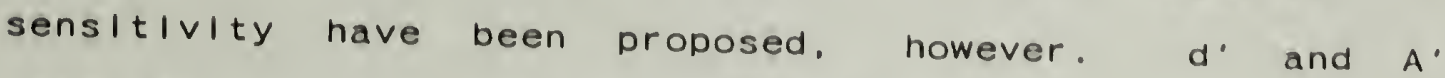
measures, two such measures deslgned to control for response blas. were also used in the current experlments. A was used because it has the capabllity of deallng with probabllitles of $O$ and 1 in the false alarm and hlt rates. repectIvely (see Grler, 1971, for detalls). In general, the pattern of results in all three experlments was the same across all measures. Therefore, I wIII concentrate on Percent Correct because It is easlest to Interpret.

In all of the analyses to follow there was a slgniflcant maln effect of block (1.e. subjects made fewer errors in the second block). However, since the block factor never Interacted with the other factors, data from both blocks have been comblned and block has been dropped as a factor.

Although Response TImes were recorded the results wIII not be reported. The times were relatively long and extremely varlable, so they have been dropped from 
consideration.

\section{Accuracy}

The primary goal of Experiment 1 was to assess the degree to which backgrounds infiuenced accuracy on the object Identiflcation task. Theoretically, this influence could be measured in the difference between the Background Consistent Condition and the Background Inconsistent Condition. However, since the objects were in different orientations in these two conditions we cannot assess the difference simply by looking at the main effect of Consistency. The Interaction between Background Presence and Consistency is the approprlate measure of background effect, since each background condition has a no background condition matched for location of the objects.

Table 1

Mean Percent Correct and Mean D' on Object Identification Task In Exper Iment 1

Background

ConsIstent

Background

Present

$66.3 \%$

$(.901)$

$58.8 \%$

$(.563)$

Background Absent
$67.2 \% \quad(.901)$

$67.8 \%$
Background Inconsistent

Note - D'in parentheses. 
The overail percent correct was $64.04 \%$. As can be seen In Tabie 1, the difference between the Consistent Background condition and Its No Background control was $0.9 \%$, while the difference between the Background Inconsistent condition and Its No Background control was 9.0\%. This Consistency $x$ Background Presence interaction was slgnlficant, $F(1,15)=$ 5.95, $p=.028$ in a two factor repeated measures Analysis of Variance. The Consistency $x$ Background Presence interaction was significant for the $d^{\prime}$ measure as well as the $A$. measure, $F(1,15)=6.29, p=.024$, and $F(1,15)=5.11, p=$ .039 , respect Iveiy.

A secondary question is whether the relativeiy good performance in the Background Consistent condition is the resuit of facllitation, or the relatively poor performance in the Background Inconsistent condition is the result of interference. In order to address this question simple effects $t$-tests were conducted on the difference between each background condition and its matching no background condition. The difference between the Background Consistent condition and its No Background control was not signiflcant, $t(15)=.414, p>.05$, whlle the difference between the Background Inconslstent and Its No Background control was signiflcant, $t(15)=3.87, p<.01$.

Finally, lets brlefiy look at the Faise Alarm and Miss data to demonstrate the trade - off between Hits and False A i arms. 


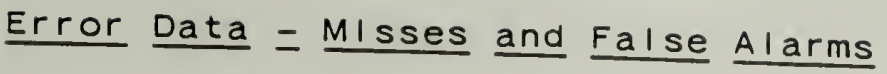

The percentage of mlsses (subject responds no when target object was cued) and the percentage of false alarms (subject responds yes when target object was not cued) can be seen In Table 2. Overall, subjects mIssed on $40.58 \%$ of the yes trlals and false alarmed on $29.6 \%$ of the no trlals. Both the miss and the false alarm data were submltted to a two way analysls of varlance. The mlss results wlll be dlscussed first.

Table 2

Mean Percent of MIsses and False Alarms for Experiment 1

Background

Present

$36.8 \%(30.9 \%)$

$59.4 \%$

$(22.7 \%)$

Background

Absent

$36.8 \%$

(29.7\%)

$29.3 \%$

$(35.2 \%)$

Note - False alarms in parentheses.

The maln effect of ConsIstency approached sIgnIflcance wlth $F(1,15)=4.21, p=.058$. The Presence/Absence of Background factor was signlflcant, $F(1,15)=16.79, p=.001$ 
and the Consistency $x$ Background Presence Interaction was highiy significant, $F(1,15)=25.50, p=.0001$.

A two-factor within subjects ANOVA was performed also on the false alarm data. The background Presence factor was marginaliy signiflcant, $F(1,15)=3.03, p=.103$ and there was a signiflcant Interaction between Consistency and Background Presence, $F(1,15)=6.54, \mathrm{P}=.022$.

As can be seen In Table 2, the drastlc Increase in misses in the Background Inconsistent condition is accompanled by a less dramatlc, but slgnlflcant, decrease in the false alarms in the Background Inconslstent condition. This trade-off suggests that subjects' criterion for responding 'no' had shlfted so that overall they responded 'no' more often in the Background Inconsistent condition, regardiess of the presence or absence of the target object.

\section{DIscussion}

Analyses of all the accuracy measures indlcated that subjects performed better on the object ldentlflcation task when the background was elther consistent with the objects or the background was not present at all. First 1 wIII discuss the difference between the background consistent condition and the background Inconsistent condition. Second I w I I address the results of the no background conditions. As outilned in the introduction, I proposed that 
backgrounds may serve two purposes: to establish depth and size cues, and to provide eplsodic information (theme or meaning of scene). The background Inconsistent scenes in this experiment were constructed in such a manner as to preserve the first function of backgrounds whlle violating the second. It is clear from the pattern of both the percent correct data and the $d^{\prime} / A^{\prime}$ data that the eplsodic Information provided by the background Influenced the subjects' responses on the object Identiflcation task. From thls we can conclude that backgrounds do more than Just provide the approprlate depth and size relationships; they are also Important In establishing the meaning of the scene. Furthermore, the data Indicate that the process of extracting the meaning from the background can be done very quickly.

It is important to note that the influence of the backgrounds in this study was not a result of some dlagnostlc features in the fovea. The portion of the scenes that fell on the subject's fovea contalned no objects and contalned no diagnostlc background features (e.g. a faucet In kltchen sink scene).

The benefit in object Identiflcation provided by the consistent background seems to conflict with a strong Interpretation of the priming model out IIned by Henderson, Pollatsek and Rayner (1987). The Intralevel priming hypothesis posits that context effects in scene perception 
can be accounted for by an object to object priming mechanism. Since the target object in the current experiment always appeared in scenes with other related objects, the degree to whlch the target object was prlmed should have been constant across all condltions. However. If we relax our definltion of what can be an object in the network and concelve of backgrounds as functioning as large objects then the results obtalned in this experiment are not Incongruent.

The finding that subjects were able to ldentlfy objects In scenes that had no background as well as they were able to Identify objects in scenes that had a consistent background may pose a problem for Blederman's object relations route to schema activation. Blederman et al. (1982) clalm that a schema for the scene is activated on the basis of accessing Information about the relationship between the objects in the scene. As I have polnted out in the Introduction, Information about the relationships between objects would not be avallable (or at least only partlally avallable) In the scenes that had no background. In the no background scenes employed In thIs exper Iment, al I the objects lacked support and vlolated most of the other Blederman relations, whlch are defined In terms of the object and the background. These vlolations should have made performance much worse in the no background condition as compared to the background consistent condition If the 
relation information was accessing a schema and object Identiflcation was facllitated by this schema. The pattern of results Indlcate that this did not happen.

It is possible that subjects' equivalent performance in the background consistent condition and the no background conditlons was produced by different, off-setting factors. Good performance in the background consistent condition could have been due to facllitation from the background. On the other hand, the good performance in the no background condition could have been the result of these scenes being "perceptually easler" since the no background scenes were conslderably less complex than the background scenes. If the first stage in scene perception is to Identify where the objects are in the scene and then parse the object from the background ( $1 . e$. declde whlch lines belong to the background and which belong to the object), then 1 t does not seem unreasonable that performance in the no background conditions was relatively good. When the no background scenes were presented, the $|n| t|a|$ parsing stage of processing the scene had al ready been done, so subjects may have had longer to ldentify the objects.

Exper Iment 1 Indicated that background Information can be utlilzed from a brlef (150 ms.) display of a scene. However, many questions remaln. In Exper Iment 1 the target object was always presented along with related objects. As a result, it cannot address the role that these non-cued 
objects mlght have played. Furthermore, we are unable to determine precisely why performance in the no background condition was as good as performance in the consistent background condition. The next two experiments wIII address these Issues. 


\section{EXPERIMENT 2}

\section{Introduction}

Experiment 1 demonstrated that background information Influenced performance on the object identiflcation task. even though the subject's exposure to the scene was brlef. In Experiment 1, however, all scenes conslsted of a target object with related objects in one of the background conditions. Because objects were presented as a set, it is not clear what effect the non-cued objects had on Identiflcation of the cued object. Henderson, Pollatsek and Rayner (1987) have found evidence for objects priming related objects. It is possible that in Experiment 1 noncued objects did prime ldentiflcation of the cued object, but that the effect of this priming was constant across all conditions.

Experiment 2 is an attempt to sort out the effects of non-cued objects from the background effects. Posslbly. both related objects and consistent background facllitate object Identification. In this experiment subjects were presented with scenes that elther had a consistent background, an Inconslstent background or no background, as In Experiment 1. In contrast, the target object in Exper Iment 2 was presented elther with four related obJects or with four unrelated objects. In this way the 
Independent roles of the cohort object set and background can be tested.

\section{Method}

\section{Subjects}

Sixteen different University of Massachusetts undergraduates particlpated in this experiment for extra credit in psychology courses. An experimental session lasted approximateiy 55 minutes.

\section{Scenes}

The 128 scenes were composed from the same or Iginal 16 scenes as in Experiment 1. These 16 scenes were grouped into 8 palrs as outilined in Experiment 1. The objects in one scene of the palr were switched with objects in the other scene pair resulting in 16 inconsistent background scenes. In order to test the role of cohort objects, one object was selected from each scene and switched into the Inconsistent background, leaving the other four objects consistent with the background. An example may help to lliustrate thls: The Bedroom scene and the Refrlgerator scene were palred together. In the Background Consistent condition bedroom oblects appeared with the bedroom background. In the Background inconsistent condition, bedroom objects appeared with the refrlgerator background (so far this is the same as Experiment 1). In the 
background cons/stent/target not with cohorts condition the doli (bedroom object) appeared In the bedroom background with four refrigerator objects. In the background inconslstent/target not with cohorts condition the suitcase (bedroom object) appeared in the refrigerator with four refrigerator objects. Each of these four conditions had matching no background conditions (as in Experiment 1) resulting in 8 conditions (see Table 3 for summary of the scene conditions).

Table 3

Exampie of Scene as it Appears in the Conditions of ExperIment $\underline{2}$

\begin{tabular}{|c|c|c|}
\hline & $\begin{array}{l}\text { Background } \\
\text { Consistent }\end{array}$ & $\begin{array}{l}\text { No background } \\
\text { Consistent }\end{array}$ \\
\hline $\begin{array}{l}\text { WIth } \\
\text { Cohorts }\end{array}$ & $\begin{array}{l}\text { Target = Doli } \\
\text { Bedroom background } \\
\text { with bedroom objects }\end{array}$ & $\begin{array}{l}\text { Target = Doll } \\
\text { No background } \\
\text { with bedroom objects }\end{array}$ \\
\hline $\begin{array}{l}\text { Not With } \\
\text { Cohorts }\end{array}$ & $\begin{array}{l}\text { Target = Doll } \\
\text { Bedroom background } \\
\text { with fridge objects }\end{array}$ & $\begin{array}{l}\text { Target }=\text { Doli } \\
\text { No background } \\
\text { with fridge ob Jects }\end{array}$ \\
\hline & $\begin{array}{l}\text { Background } \\
\text { inconsistent }\end{array}$ & $\begin{array}{l}\text { No background } \\
\text { inconsistent }\end{array}$ \\
\hline $\begin{array}{l}\text { With } \\
\text { Cohorts }\end{array}$ & $\begin{array}{l}\text { Target = Sultcase } \\
\text { Frldge background } \\
\text { with bedroom objects }\end{array}$ & $\begin{array}{l}\text { Target = Suitcase } \\
\text { No background } \\
\text { with bedroom objects }\end{array}$ \\
\hline $\begin{array}{l}\text { Not With } \\
\text { Cohorts }\end{array}$ & $\begin{array}{l}\text { Target = Sultcase } \\
\text { Fridge background } \\
\text { with fridge objects }\end{array}$ & $\begin{array}{l}\text { Target = Sultcase } \\
\text { No background } \\
\text { with frldge objects }\end{array}$ \\
\hline
\end{tabular}


In order to avold culng the same target object in each of the elght conditions, two target objects were selected from each object set (doll and sultcase in the example above). These objects were selected on the basls of an analysis of the Items from Experlment 1. All target Items selected were ldentifled correctly $75 \%$ of the $t$ ime in Exper Iment 1 . Objects were positioned In the background in the same places as In Exper Iment 1. The slze of the scenes, slze of the objects and distance between objects and the flxation polnt was the same as In Experiment 1.

\section{Deslgn}

Each subject saw each of the 128 scenes one time. However, because of the overlap between scenes each subject saw each background 4 times, each set of non-cued objects four times and each target object 4 times. On half the trlals the target object name was presented and on half the trlals the name of an object not in the scene was presented. The correct answer (yes or no) was counterbalanced across conditions. Trlals were presented in a random order, with the restriction that no two consecutive trlals had the same target object.

\section{Apparatus and Procedure}

The apparatus and procedure employed In thIs experiment 
were the same as In Experiment 1.

\section{Results}

As In Exper Iment 1, a trade-off between HIts and False Alarms required that some measure of sensitivity be computed. In the current experiment, some subjects had hit rates of 1.00 and false alarm rates of 0.00 in some conditions. For this reason d' cannot be computed. However, the non-parametrlc measure of sensitivity, $A^{\prime}$, can deal with probabllitles of 0 and 1 . A' can be Interpreted as the best estimate of what the percent correct would have been If a forced-cholce procedure had been employed Instead of a presence-absence procedure.

\section{Accuracy}

As with Experlment 1 the approprlate measure of the effect of Background Consistency is the Background Presence $x$ Background Conslstency Interaction. The overall percent correct was $65.45 \%$. 
Table 4

Mean Percent Correct In Experiment 2.

$\begin{array}{ll}\text { Background } & \text { No Background } \\ \text { Consistent } & \text { Conslstent }\end{array}$

With

Cohorts

$66.4 \%$

$68.8 \%$

Not With

Cohorts

$69.5 \%$

$73.5 \%$

Background

Inconsistent
No Background

Inconsistent

With

Cohorts

$57.1 \%$

$65.4 \%$

Not WIth

Cohorts

$54.9 \%$

$68.0 \%$

Table 4 displays the percent correct for each condition. Collapsing across cohort for the moment, it can be seen that the effects of Experiment 1 have been replicated. The difference between the Background Consistent condition and Its matching No Background condition was $3.2 \%$, whlle the difference between the Background Inconslstent and Its No Background condltion was 10.7\%. This Interaction was signiflcant, $F(1,15)=6.47$, $p$ $=.0225$. The pattern of data for the A' measure was 
similar, but the Consistency $x$ Background Presence Interaction was only marginaliy signiflcant, $F(1,15)=2.97$, $p=.1054$

Table 5

Mean $A^{\prime}$ for Experiment 2 .

Background Present
Background Absent

To determine the effect of cohort set, two results might be of Importance. If it is assumed that the role cohorts play in object Identiflcation is independent of background, then a main effect of the cohort factor should be evident. However, If cohort set affects object Identiflcation differentiy when the background is present or absent, or when the background is consistent or Inconsistent then a Cohort $x$ Background Presence $\times$ Consistency interaction would be present in the data. A three factor within subjects ANOVA performed on the data Indlcated that there was no effect of Cohort set, elther as a main effect, F $<1$, or Interacting with Background Presence and 
Consistency, $F<1$. There was no effect of cohort evident

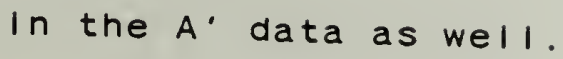

Error Data $=$ MIsses and False Alarms

The percentage of $\mathrm{mlsses}$ and the percentage of false alarms can be seen In Table 6 . Overall, subjects mlssed on $35.36 \%$ of the yes trials and false alarmed on $33.6 \%$ of the no trials. Both the miss and false alarm data were submitted to a three way Analysis of Varlance. The miss results wIIl be discussed first.

The maln effect of Consistency was signiflcant $F(1,15)$ $=34.33, p=.0000$, as well as the maln effect of Background Presence $F(1,15)=25.56, p=.0001$. There was no nint in the miss data of any effect from the cohort factor. The Consistency $x$ Background Presence Interaction was sIgn|flcant, $F(1,15)=28.53, p=.0001$.

The pattern of the false alarm data looks slightly different than the $\mathrm{m} I \mathrm{ss}$ data. In the false alarm data there was a main effect of Target With Cohorts, $F(1,15)=8.05, p$ $=.0125$. False alarms Increased when the cued object appeared with objects that were plauslbly cohorts. The only other significant effect was the Consistency $x$ Background Presence Interaction $F(1,15)=8.64, p=.0102$. 
Table 6

Mean Percent MIsses and False Alarms for ExperIment 2.

Background

Consistent

No Background

Conslstent

WI th

Cohorts

$24.6 \%$

(41.2\%)

$25.0 \%$

(37. 3\%)

Not WIth

Cohorts

$23.5 \%$

(36. $1 \%)$

$23.5 \%$

(28. $4 \%)$

WI th

Cohorts

$57.8 \%$

(29.0\%)

$29.7 \%$

$(40.6 \%)$

Not WIth

Cohorts

$66.6 \%$

(22. $8 \%)$

$31.1 \%$

(33. $4 \%)$

\section{DIscussion}

The percent correct data and the A prlme data (to a lesser degree) repllcate Experlment 1. SubJects performed equaliy well in the no background conditions as in the background consistent conditions. Furthermore, performance dropped when the background was inconslstent with the target object as compared to the background consistent condition where the background was consistent with the target object. 
Perhaps the most surprising result from Experiment 2 is that It made no difference whether the target object was surrounded by consistent or Inconsistent cohort objects. It Is particularly interesting that, even in the no background conditions, there was no effect of cohort set. It seemed I Ikely that without background to ald in obtaining the "theme" of the scene, subjects might be able to utllize Information from the surrounding objects more. This was not the case. First I would I Ike to discuss the ramiflcations of these results for Blederman's object relations model. Then, I wIII discuss the Impllcations of these results for the object to object primIng model out I Ined by Henderson et al.

Blederman et al. (1982) clalmed that the route to schema activation was through Identiflcation of the relationships between objects. In the current experiment, the target object violated the probablilty relation in some conditions (the degree to which an object is IIkely to occur In the scene) no matter how one defines probabllity (with respect to the background, with respect to the other objects, or wIth respect to both). Even in the strongest case of violation, where the background and all non-cued objects were from the same scene and only the target object was Inconslstent, only an effect of background was obtalned.

This calls Into question Blederman's route to schema activation. The Information subjects were obtaining from 
scenes where the target object was not with its cohorts should have been degraded and schema activation should have been slowed or possibly inhlbited altogether. The discrepancy between the current data and those obtalned by Blederman et al. Is particulariy surprising since care was taken to ensure that the object ldentiflcation task employed In this experiment was the same as the task used by Blederman et al. I have essentlally not replicated Experlment 1 of Blederman, Mezzanotte, and Rablnowitz $(1982)$.

Exper Iment 1 Indlcated that the Henderson et al. object to object primlng model would have to be modifled: If the background functions as a large object priming other objects then, a priming explanation can account for the decrement in performance when the background is Inconsistent. However, even this modified version of this model cannot readily account for the lack of effect of cohorts in this experiment. According to the priming mechanism, we should have seen a beneflt when the target object was presented with cohorts as opposed to belng presented with unrelated objects.

There are some posslble explanations as to why Henderson et al's model does not flt these data. One possiblilty is that the task used in this experiment taps processing at a conslderably later stage. Henderson et al's object priming effects were reflected in fixation durations, 
whlle the subject had conslderably more time to look at the object. Subjects in the current experiment saw the scene for only $150 \mathrm{~ms}$. and never had the object in thelr foveal region. Probably the most Important difference between Henderson's priming paradigm and the current methodology Is the difference between objects belng presented foveally or parafoveally. The current object ldentlfication task may have been tapplng some reconstructive process that subjects engaged In after the scene was no longer present. ThIs posslbIllty wIII be discussed In more detal In the General Discussion.

Another possible explanation for the lack of priming effects in the current experiment has to do with what should prlme what. Henderson et al's priming was achleved with objects that were semantlcally related (1.e. Doctor - Nurse) and not necessarliy eplsodically related. This is not to say that Doctors and Nurses cannot co-occur in the same scene, because of course they can. However, the stimull In the current experlment were always eplsodically related but many times were not semantically related (1.e. Doll Sultcase). Both a doll and a sultcase can easlly occur together In a bedroom scene, but they are not semantlcally related. Taken out of the context of the bedroom, one would predlct I Ittle priming of doll from sultcase and vice versa. ThIs too wIII be discussed further In the General Discussion. 
In conciusion, it appears that the degree to which the background is consistent with the target object has a rather large effect, whereas the degree to whlch the non-cued objects are conslstent with the target object has little or no effect. 


\section{EXPERIMENT 3}

\section{introduction}

At this point we know that the degree to which a background is consistent with the target object predicts performance on the object identification task. However, we do not know preclsely in what manner the backgrounds are operating. If we assume that having a conslstent background facilitates object identification, then there is a probiem reconciling the results from the no background conditions. If facliltation from the appropriate background alds object Identification, then performance in the no background control conditions should have been worse than in the background consistent condition. However, to accept the no background controls as the approprlate baseline in this object identiflcation task one would have to argue that there is no facliltation from the consistent backgrounds, only interference from processing an inconsistent background.

There is reason to belleve that the no background conditions are really not the approprlate control condition. As outlined In the discussion of Experlment 1, much is left uncontrolled in the no background condition. No background conditions not only lack the "theme" Information that background conditions have, but they are also less complex. 
Subjects may be able to ldentify more objects in the no background conditions because they do not have to first Identify where the objects are and parse the objects from the background. A better control would be one that preserved background complexity, yet had no real meaning. The purpose of Experiment 3 was to test the consistent and Inconsistent background effects agalnst a more approprlate control condition.

\section{Method}

\section{Sub Jects}

Twenty-four different University of Massachusetts undergraduates and University of Massachusetts graduate students in psychology participated in this experiment. The undergraduates recelved extra credit in psychology courses for their participation. An experimental session lasted approximately 55 minutes.

\section{Scenes}

The same 16 orlginal scenes were employed as the consistent background scenes. Inconsistent background scenes were created from these original 16 scenes in the same manner as Experiment 1. Instead of no background control conditions, Nonsense Backgrounds were used as a control. Nonsense backgrounds were created by distorting 
the or Iglnal backgrounds in order to delete the "theme" Information contalned in the backgrounds. Distortions were created with the following crlterla in mind: nonsense backgrounds should not look I Ike the or IgInal backgrounds: subjects should not be able to name these backgrounds: roughly the same number of IInes and angles should be employed In the nonsense background as in the or IgInal: nonsense backgrounds should preserve a three dimensional quality. The nonsense backgrounds resulting from this set of crlterla did not appear as a random set of I Ine segments, but as a "coherent" background that lacked any theme Information. An Informal pllot test of the backgrounds Indicated that subjects could not attach a name to the backgrounds. Even pllot subjects who were famlliar with the or IgInal backgrounds were unable to ldentlfy whlch nonsense background was constructed from whlch or Iglnal background. It was Important to preserve the three dimensionallty of the nonsense backgrounds in order to provlde planes on whlch objects could be supported. ThIs was achleved with all 16 nonsense backgrounds. The objects were sltuated in the nonsense backgrounds in exactly the same places as they were In the no background conditions of the prevlous studies.

\section{DesIgn}

The deslgn of Experlment 3 was essentlally the same as Experiment 1. The only difference was that Instead of no 
background control conditions, the nonsense background controls were employed. Each object was cued only once for each subject and the condition in whlch any given object was cued was counterbalanced across subjects. The correct answer, yes or no, was also counterbalanced. Trlals were presented in a random order, with the constralnt that no backgrounds were repeated on consecutive trlals, and no object sets were repeated on consecutive trials.

\section{Apparatus and Procedure}

The apparatus and procedure employed in this experiment was the same as Exper Iments 1 and 2 .

\section{Results}

As in Exper Iment 1, there was a maln effect of block in all the analyses ( $1 . e$. the second tIme through the scenes subjects performed with fewer errors). However, the block factor did not Interact $w /$ th any of the factors of Interest so In the analyses to be reported here, the data has been collapsed across block and block has been dropped as a factor.

\section{Accuracy}

As with Experiments 1 and 2 accuracy was assessed by percent correct and $A^{\prime}$. In order to assess the role of 
consistent and inconsistent backgrounds a two factor within subjects Analysis of Varlance was performed on the data. The overall percent correct was $62.0 \%$. Subjects were $3.6 \%$ more accurate in the Background consistent condition than the matching Nonsense Background condition and were $1.5 \%$ iess accurate in the Background inconsistent condition than the matching Nonsense Background.

This Consistency $x$ Background Type Interaction was significant, $F(1,23)=4.33$, $P=.0487$. Although the pattern of data was similar for the

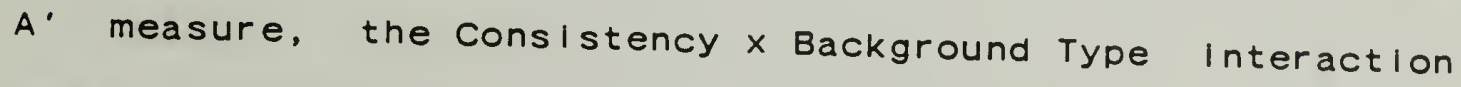
was not signiflcant, $F(1,23)=2.04, p=.1671$.

Table 7

Mean Percent Correct and Mean $A$ : on Object Identification Task for Experiment 3 .

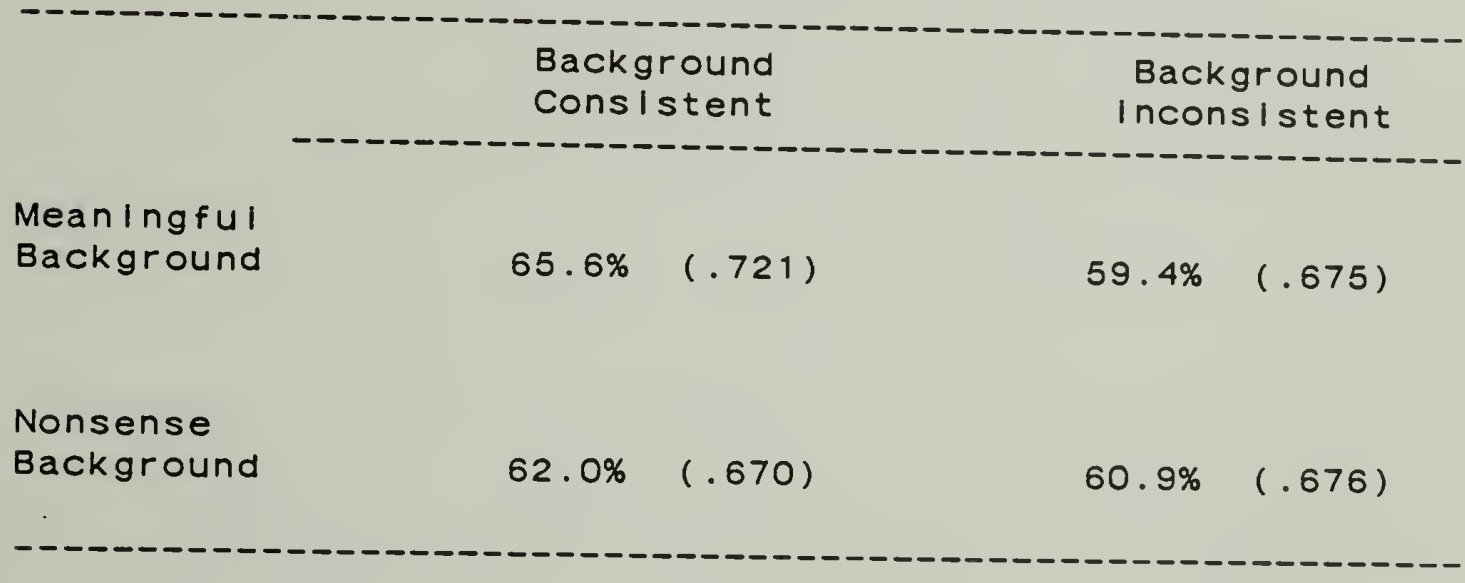

Note - A primes in parentheses.

The primary purpose of conducting Experiment 3 was to 
determine if the good performance in the Background Consistent condition was due to facliltation or whether the poor performance in the Background inconsistent condition was due to interference. In order to assess this, simpie ttests were performed between the Background Consistent condition and Its matching Nonsense Background condition, and between the Background inconsistent condition and Its Nonsense Background control. As can be seen In Table 7, the difference between the Background Consistent condition and the Nonsense Background condition was $3.6 \%$. Thls difference was slgnificant, $t(23)=2.096, p<.05$. The difference between the Nonsense Background and the Background Inconsistent condition was $1.5 \%$ and this was not signiflcant. The difference between the Background Consistent and the Nonsense Background on the $A$ ' measure was .061. This difference was significant with a one talled ttest, $t(23)=1.953, p<.05$. The difference between the Nonsense Background and the Inconsistent Background condition was .001 for the $A$ ' measure. Thls difference was not slgniflcant.

Error Data $=\underline{\text { MIsses and False Alarms }}$

The percentage of misses and false alarms for each condition can be seen in Table 8 . Overall, subjects missed on $48.8 \%$ of the yes trials and false alarmed on $27.2 \%$ of the no trials. ANOVAS were performed on both the miss and false 
alarm data. The miss results wlll be discussed first.

Table 8

Mean Percent MIsses and Faise Alarms for Experiment 3.

\begin{tabular}{|c|c|c|c|c|}
\hline \multirow[b]{2}{*}{$\begin{array}{l}\text { Mean Ingful } \\
\text { Background }\end{array}$} & \multicolumn{2}{|c|}{$\begin{array}{l}\text { Background } \\
\text { Consistent }\end{array}$} & \multicolumn{2}{|c|}{$\begin{array}{l}\text { Background } \\
\text { Inconsl stent }\end{array}$} \\
\hline & $38.6 \%$ & $(30.8 \%)$ & $57.3 \%$ & $(22.9 \%)$ \\
\hline $\begin{array}{l}\text { Nonsense } \\
\text { Background }\end{array}$ & $47.4 \%$ & $(28.7 \%)$ & $51.8 \%$ & $(26.6 \%)$ \\
\hline
\end{tabular}

Note - False Alarms in parentheses.

The two signiflcant effects in the miss data were a maln effect of consistency $F(1,23)=17.84, p=.0003$, and the Consistency $x$ Background type Interaction, $F(1,23)=$ 19.52, $\mathrm{p}=.0002$. As can be seen In Table 8 subjects missed more frequently in the background Inconsistent and the nonsense background conditions than in the background consistent conditions.

Analysis of the False Alarm data revealed a main effect of. Consistency, $F(1,23)=4.97, D=.0359$ as the only slgniflcant effect. 


\section{Discussion}

The results of the consistent and Inconsistent Background conditions In Experiment 3 replicated the findings of Experlments 1 and 2. The most Interesting result from the current experiment, however, Is the fact that backgrounds that are eplsodically consistent seem to be facliltating object ldentiflcation whlle backgrounds that are eplsodicaliy Inconsistent appear not to Interfere.

It thus appears that the no background conditions employed in Experlments 1 and 2 were not the approprlate baseline upon which to Increment facllitation versus Interference. The good performance on no background conditions was apperantly due to the fact that these scenes were perceptually easler. The nonsense background employed In the current experiment is a more reasonable control condition. Subjects still had to Identify where the objects were located in the scene and parse the objects from their background, but attention and capaclty spent processing the background would not have alded the subject in the object Identiflcation task.

One assumption about the processing of scenes must be made, however, If one is to belleve that the nonsense backgrounds were an adequate control. The assumption is that processing of the background must go on in parallel, to some extent, with the processing of the objects. If a strictiy serlal model of processing is assumed, (one that 
says Identify backgrounds first, don't continue unt II background has been ldentlfled, and then Identlfy objects with remalning $t$ Ime) then It could be argued that all of the tIme when the scene was visible was spent attempting to make sense out of the nonsense background, and thus the subject never had time to Identify the objects. However, If this were the case subjects should not have been any better than chance in the nonsense background condltion and they did perform slgniflcantly better than chance.

The pattern of "benefit" from conslstent backgrounds and no "cost" from the Inconsistent backgrounds is Interesting from an ecologlcal valldity vlewpolnt. Had the results been In the opposite direction, that Is, all cost for Inconsistent background and no benefit for consistent background, then one mlght have argued that the results were less Interesting. After all, how often In "real-world" perception do we see refrlgerator objects in the bedroom, or vice versa? The results obtalned from Experlment 3 fit nlcely with how one might expect the perceptual system to work; that Is, conslstent Information facllitates object IdentIfication, but Inconsistent information does not Interfere. If Inconsistent Information Interfered then one would be at a real disadvantage in identifylng an object when that object was Inconsistent. ThIs would predlct that If a IIon were In your IIving room it would take you a long time to Identify that it was a I Ion. ThIs organlzation 
would not be very adaptive.

It is difficult to acertaln whether beneflt from consistent Information with no cost for Inconsistent Information is predicted by schema activation, because it has not been made expliclt in models of schema activation whether activating the wrong schema Interferes or whether actlvating the right schema facllitates, or both.

The pattern of benefit from consistent Information and no cost from Inconsistent Information was also observed in flxation duration data reported by Henderson et al. Henderson et al. found that having a related object In the fovea prlor to flxating the target object resulted in faster naming times to the target object. Furthermore, he found that having an unrelated object as the prime did not Interfere with naming as compared to a neutral baseline. ThIs Issue of facliltation versus inhlbition wIII be discussed further In the general discussion. 
All three experlments reported here demonstrated that scene backgrounds play a role In object Identiflcation when the scene is presented for a brlef duration: the degree to which a background is consistent with the target object predicts performance on the object Identlfication task. In addition, Experiment 2 Indlcated that there is no effect of the surrounding, non-cued cohort objects on this process. Finally, Experiment 3 showed that the relatively good performance in the Background Consistent condition is the result of facllitation and the relatively poor performance In the Background Inconsistent condition is not the result of Interference.

These results (particularly the results of Experiment 2) pose some problems for the object relation route to schema activation as proposed by Blederman et al. (1982). Experlment 2 did not replicate his finding that subjects perform worse on the object Identlflcation task if the target object is undergolng a violation. I would conclude from this that Blederman's conception of what activates a schema and how that schema operates is not quite accurate.

In the Introduction, I outIIned Blederman's model for schema activation. He assumes that some relations between objects can be understood before the objects are fully 
Identifled (I.e. the syntactic relations, support and Interposition). I have argued that this is not a valld assumption. Blederman et al. clalm that these relations between objects are responsible for activating the approprlate schema for the scene. Furthermore, they claim that the schema that is activated then facllitates further Identification of objects. They assert that when an object is undergolng violation, the correct schema can be accessed but that this schema activation Interferes with Identifylng the object undergolng violation. Presumably this Interference occurs because the schema dictates not only what objects can occur in the scene, but where those objects are likely to occur. Experiment 2 in the present serles of studies does not provlde any evidence that object relation Information dictated which schema should be activated and that this schema Interfered with the Identiflcation of the cued object. If this were the case, subjects should have performed worse in the background inconsistent condition when the target object was not with its cohorts than when it was with lts cohorts. Thls was not the case. However, It should be noted that Experiment 2 was only able to address the relation of probabllity. The other relations, support, interposition, position, and size were not directiy manlpulated In any of the present experlments.

The question then presents Itself, can we modify Blederman's schema activation model to account for the data 
presented here? The obvious possiblilty is that the background activates the schema instead of object relations. Perhaps subjects rapldiy identify the background as well as partially ldentify some of the objects. Thls information, mostly background Information, accesses a schema for this scene and the schema facliltates object identification. The evidence presented here may be conslstent with this view, but does not exclusively polnt to thls Interpretation.

The backgrounds employed in these three experiments were falrly constralned in that the theme of the scene was clear from the background. By this I mean that the $k$ Itchen slnk scene was constructed in such a way that it could only be a kltchen slnk and would not be confused with a bathroom slnk or with any other background. But what would happen if the backgrounds were less constralned so that the Information obtalned from ldentifylng the background did not necessarily predict what the scene was about? If schema activation is a result of correctly ldentifying the background, then one of three things could happen if scenes were constructed wlth "generlc" backgrounds. When presented with nondescrlpt backgrounds subjects might settle on one Interpretation of the background, access that schema and If they were right, facliltation should occur, whereas if they are wrong the schema should Interfere. Thls option does not seem very plauslble because they would on average be wrong more than right. Another possiblilty is that the generic 
background may access schemas for all scenes that could plauslbly have that background. Perhaps thls reduces the activation of any one schema so the effects of schema facliltation or Interference should be less than with descriptive backgrounds. Finally, schemas may only be activated when the backgrounds are complete enough to falriy accurately access the correct schema. In this case there should be no effect of generlc background over the nonsense background. Unfortunately, the data from the current experiments cannot address this issue so a definitive answer must walt untll the approprlate experlment is done.

To summarize, although we can not rule out that schema activation might have been playing a role in the current experlments, we can conclude that Blederman's route to schema activation may not be correct. At this polnt 1 would IIke to move on and discuss the ramlflcations of these data for the entirely bottom-up approach to scene context effects as outlined by Henderson et al.

Henderson et al. has provided evidence that an object flxated prlor to fixating a target object can facliltate Identiflcation of the target object if the previously flxated object was semantlcally related (1.e. dog primes cat, coat primes hat). The evidence from the current exper Iments does not entirely support $\mathrm{hls}$ clalm that these sorts of priming effects can account for scene context effects. There are some reasons however, why the current 
results may differ from those presented by Henderson et al. In the following section 1 wll explaln these differences and the extent to which these differences mlght or might not affect the conclusions drawn by Henderson.

In lts purest form, the object to object priming hypothesls would predlct that there should be no effect of background on the object ldentiflcation task, since the only facllitation should result from other non-cued objects priming the target object. The data presented in these three experiments is in direct conflict with this hypothesis. The major finding was the Influence of background Information on object Identlflcation, and there was no effect of the cohort or non-cued objects in Experiment 2. As I Indicated In the discussion of Exper Iment 1 , we can reconclle the first finding (role of backgrounds) with the Henderson model If we assume that backgrounds are operating much as objects do, only that they are easler to Identlfy because they are so large. However, this modification does little to help explain why we obtalned no priming from the cohort set In Experiment 2. For this reason I would like to further explore some of the differences in methodology to try account for these apparently confllcting results.

One posslbllity is that the measures Henderson employed (fIxation duration, naming $t$ Ime) and the measure used In the current experlments (yes/no response to object 
Identiflcation question) tap different stages in processing. Henderson et al. (1987) acknowledge thls posslbllity and claim that the object ldentiflcation task employed in Blederman's research and the present research may tap processing at a scene Integration stage rather than at an object Identiflcation stage. That Is, objects that are conslstent wlth the scene context are more easlly Integrated Into the representation of the scene and therefore less I Ikely to be lost from a memory buffer In whlch the presence or absence of the target object is read from. It is not possible in the context of the current experiments to localize the effects to a speclfic polnt in the time course of processing.

Henderson et al. also clalm that, to the extent to whlch the priming mechanlsm is automatlc, it should occur in all scene processing even If post-perceptual processing is occurring. Evidence for thls automatlc priming between related objects was not observed in the current research. However, the objects may have to be flxated (or at least be close to fixation) In order for the priming to occur. In the current experiments none of the cohort objects were flxated and all were greater than 2 degrees from fixation. On the other hand, the evidence obtalned from Experiment 3 does suggest that automatic processing is occurring. To the extent there was a benefit and no cost related to the eplsodlc approprlateness of the background 
Indlcates that these effects are not due to some consclous problem solving strategy. If a consclous problem solving strategy was employed by the subject that resulted in the subject making predictions about what was present in the scene then there should have been interference effects In the Background Inconsistent condition as well as facliltation In the Background consistent condition.

An assumption that must be made in order for object to object prImIng to account for scene context effects is the assumption that objects whlch fIt In the scene are more I Ikely to be semantically related to one another than objects that could not fit in the scene. I am not convinced that this assumption is completely valld. The present experlments did not demonstrate any cohort effects. For the sake of argument, however, lets assume that a cohort effect would be observed If the objects had been flxated. For example, a doll and a sultcase both appeared In the bedroom scene of this experlment and were responded to as if they were conslstent with the scene context (I.e. subjects made relatively few errors). A carton of mlik was put in the bedroom background in the Background Inconsistent condition and subjects responded to the carton of mIIk as though It was Inapproprlate in this context (subjects made more errors). It is hard for me to belleve that "sultcase" and "doll" are more semantlcally related than "carton of mlik" and "doll". So It seems as though the valldity of the 
priming mechanism for plcture perception is dependent upon how one defines what should prime what. Many objects used In the current experiments may not be considered "semantically related" meaning that they are not from the same semantic category. Furthermore, most objects in these experiments are not strong assoclates of one another (as were the objects used by Henderson). However. Henderson used semantic assoclations between objects and this may not be approprlate. Perhaps the underlying principle concerning what should prime what is the frequency of co-occurence of the objects in the real-world.

In conclusion, there are some reasons why Henderson et a 1. would have observed priming effects that were not apparent in the current data. However, I think the current data argue that Henderson's object to object priming mechanism cannot account for all of the scene context effects. First, It seems unlikely that background Information plays such an Important role at, perhaps, a later Integration stage, without it having some effect at an earller processing stage. Second, the priming mechanism is based upon the assumption that objects co-occurring in a scene are semantlc primes of one another. Thus, If we were to present scenes in which the objects were not semantic primes of one another but could co-occur in the scene, we should not get context effects. EvIdence from less on-line measures seems to Indlcate that context effects can occur 
even when the objects are not semantlc primes of one another. Thls leaves us with two Issues: can a priming mechanism account for the context effects if we somehow redefine what should prime what; and how do we determ Ine what should prime what? The data presented here do little to answer these questions other than to suggest that a model based on priming would have to account for backgrounds priming objects and the priming network should be organlzed according to episodic co-occurence, rather than semantic relatedness.

Up to this polnt I have trled to indlcate how two extremely different models of scene perception would have to be altered In order to account for data from the current exper Iments. The route to schema actlvation would have to be changed from object relations to some other route. The current data suggest that, at least when the backgrounds are constralning enough and when there are no foveal objects, then background Identiflcation may be the route to schema activation. Furthermore, the data suggest that once the appropriate schema is activated, the effect of the schema is only facilitory and not Inhlbltory. In order for a priming mechanism to account for the current data, the priming network would have to be organized on the princlple of eplsodic co-occurence, not semantlc relatedness.

Furthermore, it must be assumed that backgrounds can operate like large objects in thls eplsodlcally arranged network. 
The current data cannot distingulsh between the revised schema model or the revised priming model. Thls must awalt further research.

The research presented here has contrlbuted to our knowledge about scene processing. First, we have demonstrated that "schema-like" effects can be achleved even when there are no dlagnostlc objects or dlagnostlc features In the fovea. The background effects obtalned in all three of the experiments reported here Indlcate that subjects can Identify backgrounds even though in order to do so they must process Information that is presented peripherally as well as foveally. Second, It appears that context effects due to background are facllitory in nature and not Inhibltory. Future models of scene processing should not only account for context effects in terms of other objects in the scene, but should explicltiy include the facliltating role that backgrounds can play in object Identlflcation. 


\section{APPEND IX}

* Indlcates non-cued object

\section{Scenes and Objects}

1. Bedroom

\section{DIstractors}

(Refr Igorator)
1. Teddy Bear
2. Doll
3. Sultcase
4. Baseball Cap
5. Pennent *

1. Radlo

2. Alarm Clock

2. Broom Closet

(Desk)
1. Iron
2. Scrub Brush
3. Paper Towels
4. Bucket
5. WIsk Broom *

1. Vaccuum Cleaner

2. Dust Pan

3. Clothes Closet (Oven)
1. Pants
2. Bowtle
3. Glove
4. Shoe
5. Hat *

1. Coat

2. Sock

4. Construction (Porch)
1. Dr I |
2. Hammer
3. Saw
4. Saw Horse
5. Ladder *

2. Wrench 
5. Desk

(Broom Closet)

1. Brlefcase

2. Lamp

3. Phone

4. Stapler

5. Plcture*

1. Pad of Paper

2. Ruler

6. DIner

(Shower)

1. Coffee Cup

2. Fork

3. Salt Shaker

4. Syrup PItcher

5. Ketchup *

1. Menu

2. Plate

7. Fireplace

(Laundry)
1. Candle
2. Chair
3. Clock
4. Logs
5. Bellows*

1. Matches

2. Poker

8. Refrlgerator

(Bedroom)
1. Butter
2. Cheese
3. Lettuce
4. MIIK
5. OnIon *

1. SIX Pack

2. Egg Carton

9. Laundry

( $F \mid$ rep Iace)

1. Laundry Basket

2. Laundry soap Box

3. Hanger

4. ShIrt

1. Clothes PIn

5. Bleach *

2. Hamper 
10. Oven

(Clothes Closet)

1. Sauce Pan

2. Spoon

3. Teapot

4. Turkey

1. skl|let

5. Oven MIt *

2. Spatula

11. PoOI

(Street)
1. FIIpper
2. Raft
3. $\operatorname{Gr}|1|$
4. Beach Ball
5. Llfe Saver *

1. Beach Chalr

2. Snorkel

12. Porch

(Construction)
1. BIrdhouse
2. Rollerskate
3. Pumpkin
4. Newspaper
5. Watering Can *

1. Cat

2. Flower Pot

13. Kltchen SInk

(Tollet)
1. Coffee Maker
2. Eggbeater
3. Toaster
4. WIne GIass
5. Dish Detergent *

1. Sponge

2. DIsh Rack

14. Shower

(DIner)
1. Bath Mat
2. SIIppers
3. Soap
4. Towe I
5. Shampoo*

1. Shower Cap

2. Wash Cloth 
15. Street

(PoOI)

1. BIke

2. Fire Hydrant

3. Ma I Ibox

1. Stop SIgn

4. Parking Meter

2. Traffle Llght

5. Wagon

16. Tollet

(KItchen sink)

1. Tollet Brush

2. Tollet Paper

3. Kleenex

4. Tollet PLunger

1. Alr Freshener

5. Baby Powder *

2. Waste Basket 


\section{REFERENCES}

Antes, J.R. (1977). RecognIzIng and locallzing features in 155-161.

Memory and Cognition, 5 ,

Antes, J. R. \& Penland, J. G. (1981). Plcture context Senders Eye movements: Cognltion and Flsher, Monty \& HIIIsdale: Earlbaum, 1981.

Antes, J. R., Penland, J. G., \& Metzger, R. L. (1981). plctures. Psychologlcal Research in brlefly presented Psychologlcal Research, 43, 277-292.

$\begin{aligned} \text { Blederman, } & \text { I. } \\ \text { Sclence, } 177, & (1972) .\end{aligned}$

Blederman, $1 . \quad(1981)$. Do background depth gradients
facliltate object ldent If icatlon? 578 .

Perception, 10, 573-

Blederman, I. (1982) FInal Report to U.S. Army Research
Institute.

Blederman, I., Glass, A., \& stacy, E. (1973). Searching for objects In real world scenes. Journal of Exper Imental Psychology, 1, 22-27.

Blederman, I., Mezzanotte, R. J., \& Rablnowltz, J. C. (1982). Scene perception: detecting and judging. objects undergoing relational violations. Cognitive Psychology, 14, 143-177.

Blederman, 1., Rablnowltz, J. C., Glass, A. L., \& stacy, E. W. (1974). On the Information extracted from a glance at a scene. Journal of Exper Imental Psychology, 103,

Frledman, A. (1979). Framing plctures: the role of knowledge in automatized encoding and memory for gist. Journal of Experlmental Psychology, 3, 316-355. 
Grier, J.B. $(1971)$. Nonparametric Indexes for sensit|vity
and blas: computing formulas. Psychologlcal Bulletin.
$6,424-429$.

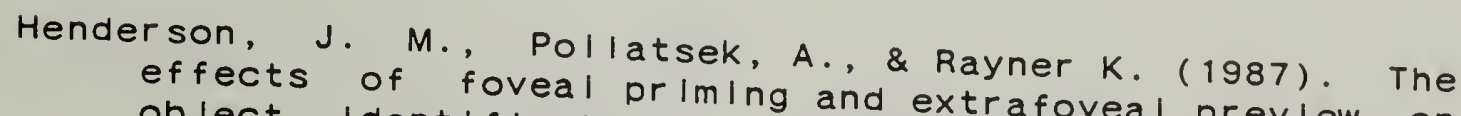
object ldentiflcation. Psychology: Human Perception and Per formancer Exper Imental Psychology: Human Perception and Performance, 3 , 449 -

Loftus, G. R. \& Mackworth, N. H. (1978). Cognltive viewing. Journal of Experimentalon during plcture Perception and Performance, $4,565-572$.

Mackworth, N. H. \& MorandI, A. J. (1967). Informative detalls within plctures. Psychophyslcs, 2., 547-552.

The gaze selects

Perception and

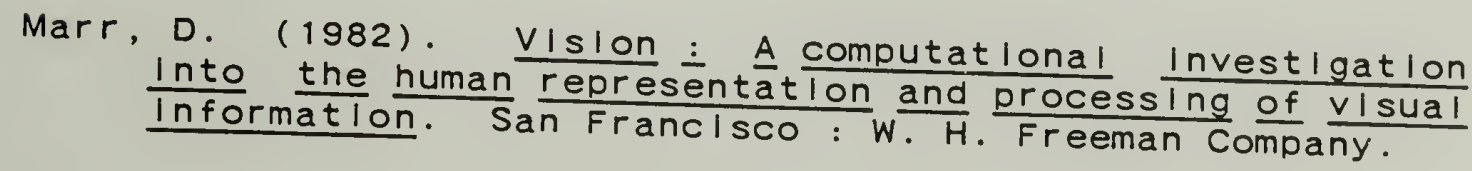

NeIson, W. W. \& Loftus, G. R. (1980). Functional visual fleid during plcture viewing. Journal of Experimental Psychology: Human Perception and Performance, 6, $391-$

Parker, R. E. (1978). Plcture processing during Perception and Performance, 4, 284-293.

Salda, S. \& Ikeda, M. (1979). Useful visual fleld slze for pattern perception. Perception and Psychophyslcs. 25. 


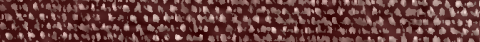

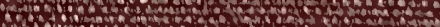
1.3. - 2 W.

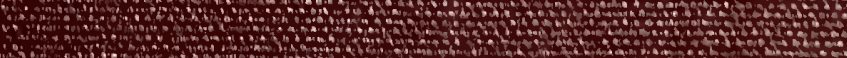

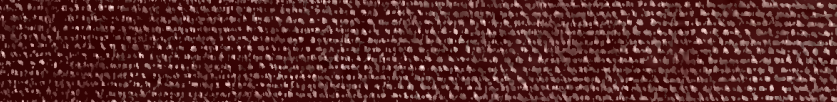

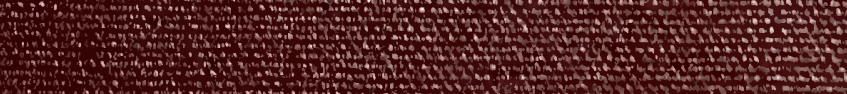
9.4.

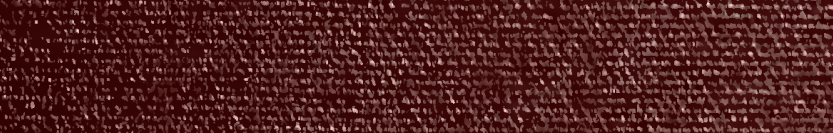

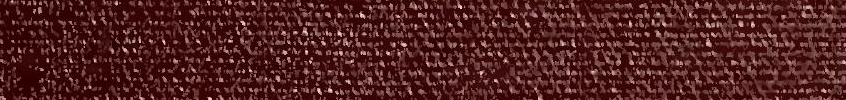
(1)

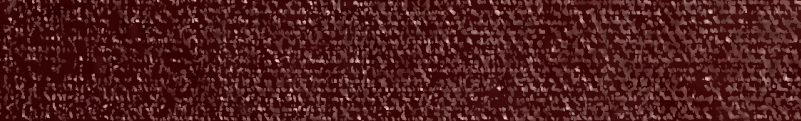
1.

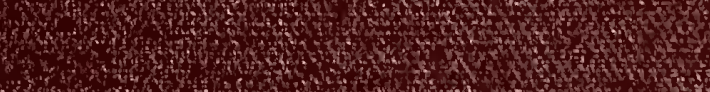

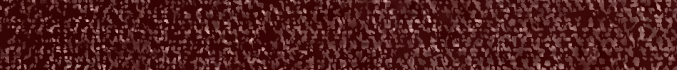
H. 1 .

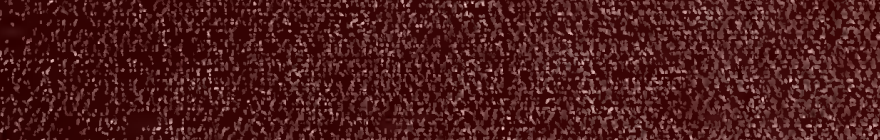

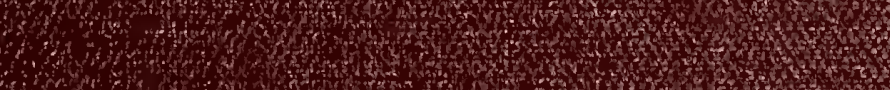
1.9
1

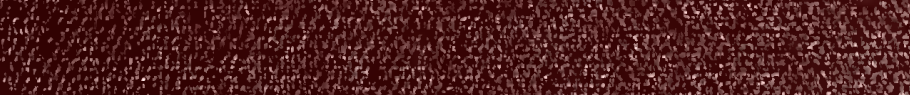

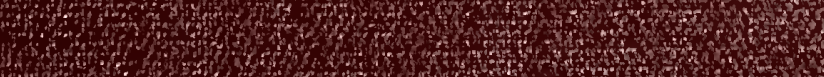

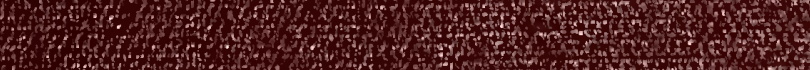

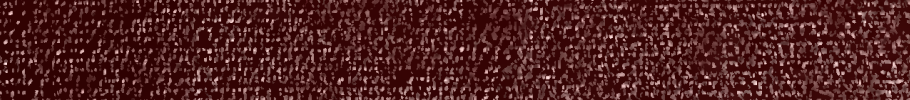
How

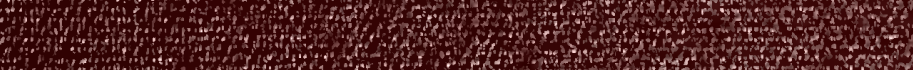

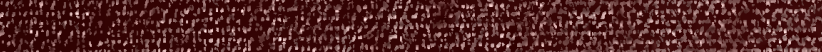

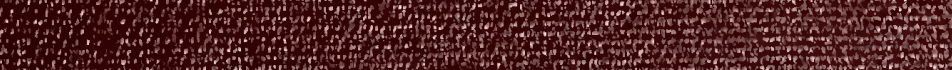

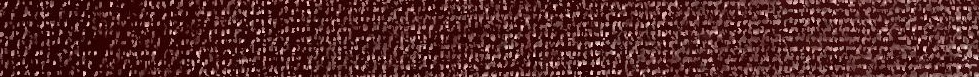
4. 6.

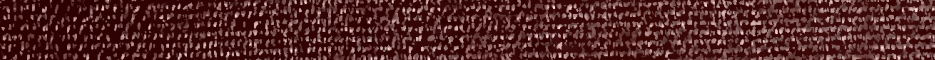

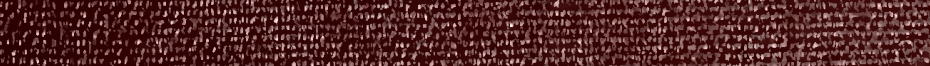

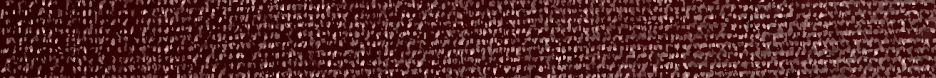

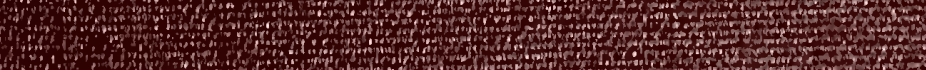
tin

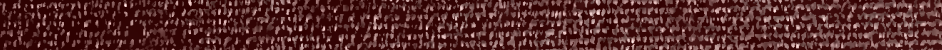

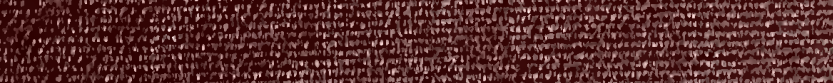

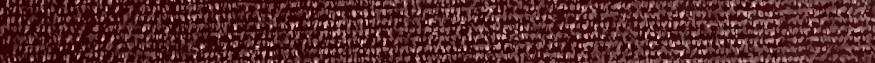
H.

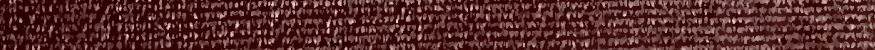

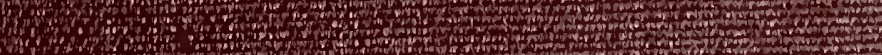

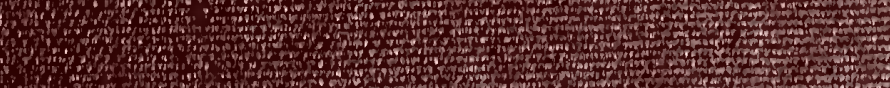

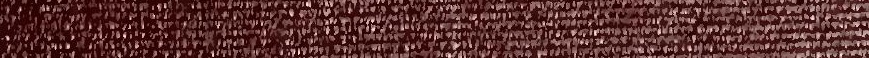

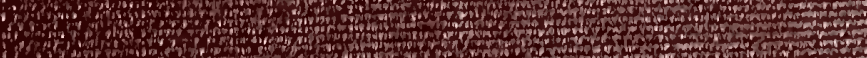

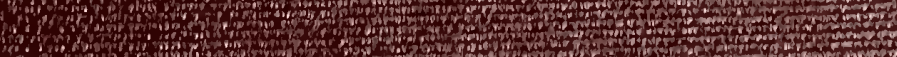

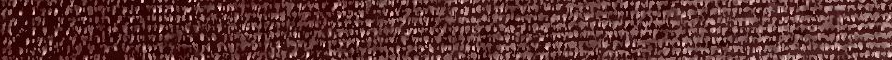

